\title{
Intervensi Ceramah Video dan Ceramah Diskusi terhadap Pengetahuan dan Sikap Remaja dalam Kesehatan Reproduksi
}

\author{
Arip Ambulan Panjaitan ${ }^{*}$, Laksmono Widagdo**), Priyadi Nugraha Prabamurti ${ }^{* *)}$ \\ *) Akademi Kebidanan Panca Bhakti \\ **) Fakultas Kesehatan Masyarakat Universitas Diponegoro \\ Korespondensi: arief.naburju92@gmail.com
}

\begin{abstract}
Background: Adolescents are one of the high risk groups to face the cases of Unwanted Pregnancies, abortion, Sexually Transmitted Infections (STIs) including HIV and AIDS. Reproductive health education as an effort to prevent risky sexual behavior that is important to be delivered to adolescents. This study aims to determine the effect of reproductive health education models through lectures followed by videos and lectures with case discussions and roleplaying on increasing adolescent knowledge and attitudes in preventing risky sexual behavior.
\end{abstract}

Method: This study is a quasy experiment with a pretest-posttest design with a control group. Data obtained using a structured questionnaire that has been tested for validity and reliability. The research subjects were class $X$ students (ten) of SMAN 2 Sintang and SMAN 4 Sintang who were selected purposively as many as 120 people. The selection of samples using purposive sampling which recruited 40 people for each group, there were two treatment groups and one group for the control. Data were analysed using paired sample t-test and independent t-test.

Results: The results of the study showed that there were no differences in the characteristics of the respondents from the two treatment groups and the control group, so that it was beneficial for this study. Likewise the level of knowledge and attitudes of respondent before intervention had no differences / homogeneous condition. Statistical results of paired sample $t$-test revealed that there were differences in the average score of knowledge and attitudes after intervention with $p$ value 0,001. Intervention with lectures and discussions including role playing has increased the knowledge and attitudes scores of respondents higher than the lecture and video methods. It was concluded that intervention using lectures with case discussions including roleplaying has improved understanding of adolescents about reproductive health and sexuality so that this method was suggested to be used as an alternative for better reproductive health education for adolescents.

Keywords: Reproductive health education, sexuality, youth, knowledge, attitudes,

\begin{abstract}
ABSTRAK
Latar Belakang: Remaja merupakan salah satu kelompok risiko tinggi terdampak kasus Kehamilan Tidak Diinginkan (KTD), aborsi, Infeksi Menular Seksual (IMS) termasuk HIV dan AIDS. Pendidikan kesehatan reproduksi sebagai salah satu upaya pencegahan perilaku seks berisiko yang penting diberikan kepada remaja. Penelitian ini bertujuan mengetahui pengaruh model pendidikan kesehatan reproduksi melalui ceramah diikuti video dan ceramah dengan diskusi kasus dan roleplaying terhadap peningkatan pengetahuan dan sikap remaja dalam pencegahan perilaku seks berisiko.
\end{abstract}

Metode: Penelitian ini adalah quasy eksperiment dengan desain pretest-posttest with control group. Data diperoleh menggunakan kuesioner terstruktur yang telah dilakukan uji validitas dan reliabilitas terlebih dahulu. Subjek penelitian adalah siswa kelas X (sepuluh) SMAN 2 
Sintang dan SMAN 4 Sintang yang dipilih sebanyak 120 orang. Pemilihan sampel menggunakan purposive sampling sebanyak 40 orang, dibagi dua kelompok perlakuan dengan masing-masing 40 sampel dan 40 orang untuk kelompok kontrol. Analisis data menggunakan uji statistik paired sampel t-test dan independent t-test.

Hasil: Hasil penelitian menunjukkan karakteristik responden dari kedua kelompok perlakuan dan kelompok kontrol tidak terdapat perbedaan, sehingga menguntungkan bagi penelitian. Demikian juga tingkat pengetahuan dan sikap responden awal sebelum intervensi mempunyai kondisi yang tidak berbeda/homogeny. Hasil uji statistik paired sample t-test diketahui terdapat perbedaan skor rata-rata pengetahuan dan sikap setelah diberikan pendidikan kesehatan reproduksi dengan $\mathrm{p}$ value 0,001 . Intervensi dengan ceramah dan diskusi kasus dan role playing memberikan peningkatan skor pengetahuan dan sikap yang lebih tinggi dibandingkan dengan metoda ceramah dan video. Disimpulkan kelompok dengan perlakuan ceramah, diskusi kasus dan roleplaying memberikan peningkatan pemahaman remaja tentang kesehatan reproduksi dan seksualitas yang lebih baik sehingga disarankan metoda ini dapat dijadikan sebagai alternative pendidikan kesehatan reproduksi remaja yang lebih baik untuk digunakan.

Kata Kunci: Pendidikan kesehatan reproduksi, seksualitas, remaja, pengetahuan, sikap

\section{PENDAHULUAN}

Menurut Health Organization (WHO) setengah dari kasus infeksi HIV di seluruh dunia terjadi pada usia di bawah 25 tahun. Demikian juga, sebanyak 111 juta kasus IMS diderita oleh kelompok usia di bawah 25 tahun. Setiap 5 menit remaja atau kaum muda di bawah usia 25 tahun terinfeksi HIV dan setiap menitnya 10 wanita usia 15-19 tahun melakukan aborsi tidak aman. Survei Kesehatan Reproduksi Remaja Indonesia (SKRRI) pada tahun 2007 menunjukkan bahwa dari 10 juta remaja, setidaknya $1 \%$ remaja perempuan dan 5-6\% remaja lakilaki mengaku telah berhubungan seksual. ${ }^{(1)}$ Hasil survei Perkumpulan Keluarga Berencana Indonesia (PKBI) pada tahun 2008 menunjukkan bahwa jumlah remaja di Indonesia berusia 10-24 tahun mencapai 65 juta orang atau $30 \%$ dari total penduduk
Indonesia. Sekitar 15-20\% diantaranya remaja usia sekolah di Indonesia sudah melakukan hubungan seksual sebelum menikah. Sekitar 15 juta remaja perempuan usia 15-19 tahun melahirkan setiap tahunnya. Hampir $80 \%$ dari kasuskasus baru infeksi HIV yang dilaporkan berasal dari usia 15-29 tahun dan setiap tahun ada sekitar 2,3 juta kasus aborsi di Indonesia, dimana $20 \%$ diantaranya adalah aborsi yang dilakukan oleh remaja. ${ }^{(2)}$

Salah satu permasalahan utama remaja adalah ketidaktahuan mereka terhadap tindakan yang harus dilakukan sehubungan dengan masalah kesehatan reproduksi. Hal tersebut ditunjukkan dengan masih rendahnya pengetahuan remaja tentang kesehatan reproduksi. ${ }^{(3)}$ Kurang tersedianya informasi kesehatan reproduksi secara komprehensif membuat remaja berusaha mencari akses dan 
melakukan eksplorasi sendiri. Oleh karena itu, remaja memerlukan informasi kesehatan reproduksi secara komprehensif sehingga diharapkan memiliki sikap dan tingkah laku yang bertanggung jawab. ${ }^{(3)}$

Melihat kondisi ini, tindakan preventif sangatlah penting dan salah satunya dengan pemberian pendidikan kesehatan reproduksi sejak dini. Semakin dini remaja menerima pendidikan kesehatan reproduksi, maka mereka akan lebih memiliki waktu untuk mengasimilasi pengetahuan kesehatan reproduksi dan lebih memiliki kesempatan untuk berlatih mengendalikan perilaku. ${ }^{(4)}$

Salah satu pihak yang mampu memberikan pendidikan kesehatan reproduksi kepada remaja secara tepat adalah sekolah. Sekolah merupakan tempat yang efektif untuk menyebarluaskan informasi, membentuk sikap dan mengembangkan keterampilan. Hal ini diperkuat oleh penelitian Speizer, Magnani dan Colvin pada tahun 2003 serta Galant dan Maticka-Tyndale pada tahun 2004 yang menemukan bahwa pendidikan kesehatan reproduksi yang diberikan di sekolah berhubungan dengan penundaan perilaku seksual dan menurunkan angka kehamilan yang tidak diinginkan (KTD) serta infeksi menular seksual (IMS) diberbagai negara. Kedua penelitian tersebut membuktikan bahwa sekolah merupakan tempat yang tepat untuk memberikan pemahaman tentang kesehatan reproduksi pada remaja. Hal ini juga didukung oleh pandangan dari para remaja bahwa pihak yang tepat untuk memberikan pendidikan kesehatan reproduksi adalah guru sekolah. ${ }^{(5)}$

$$
\text { Pendidikan kesehatan reproduksi }
$$
remaja (KRR) di sekolah merupakan salah satu upaya kesehatan untuk meningkatkan derajat kesehatan anak didik, meningkatkan kualitas sumber daya manusia, membantu remaja agar memiliki pengetahuan, kesadaran, sikap dan perilaku kesehatan reproduksi sehat dan bertanggung jawab melalui advokasi, promosi kesehatan, komunikasi informasi dan edukasi (KIE), konseling serta pelayanan kepada remaja dengan memiliki permasalahan khusus, dukungan pada kegiatan remaja bersifat positif. ${ }^{(6)}$

Pendidikan KRR melalui fasilitator merupakan salah satu cara yang efektif untuk memperoleh pengetahuan tentang kesehatan reproduksi guna meningkatkan pencegahan perilaku seks berisiko. ${ }^{(5)}$ Fasilitator merupakan orang yang membantu peserta belajar untuk memperoleh pengetahuan dan keterampilan melalui sebuah proses belajar aktif. Fasilitator dalam proses belajar aktif berbeda dengan BKKBN dalam pengajaran secara tradisional. Dalam pengajaran tradisional seorang petugas dari $\mathrm{BKKBN}$ menyampaikan informasi tentang 
kesehatan reproduksi dengan penyuluhan dan dibantu dengan booklet. Sedangkan dalam proses belajar aktif, seorang fasilitator membantu kelompok (memfasilitasi) peserta belajar mencari dan menemukan ide-ide sendiri serta menyimpulkannya.

\section{METODE}

Penelitian ini menggunakan pendekatan kuantitatif dengan studi quasi experimental dengan non equivalent control desain. Untuk mengetahui peningkatan pengetahuan dan sikap dilakukan melalui kegiatan pretest dan posttest. Dalam penelitian ini kelompok perlakuan dibagi menjadi dua kelompok, satu kelompok diberikan pendidikan kesehatan reproduksi oleh fasilitator BKKBN melalui ceramah dan booklet dan satu kelompok diberikan pendidikan kesehatan reproduksi oleh fasilitator PKBI melalui studi kasus dan diskusi kelompok. Subyek penelitian dipilih dari SMA negeri di Kabupaten Sintang. Pengambilan sampel dengan metode simple random sampling sebanyak 40 responden dipilih yang belum pernah mendapatkan pendidikan kesehatan reproduksi. Pendidikan kesehatan reproduksi diberikan oleh fasilitator $\mathrm{BKKBN}$ dan fasilitator PKBI selama 120 menit selama tiga hari dan diberi. Materi pendidikan kesehatan reproduksi diantaranya fungsi organ reproduksi, pubertas, kehamilan tidak diinginkan, keluarga berencana, kontrasepsi, aborsi dan pencegahan HIV\&AIDS dengan menggunakan metode ceramah, video, diskusi kasus, testimony dan role playing. Instrumen dalam penelitian ini berupa kuesioner dan pretest yang dilakukan sebelum diberikan pendidikan kesehatan reproduksi dan kuesioner posttest yang dilakukan sesaat setelah diberikan pendidikan kesehatan reproduksi secara lengkap. Data diolah dan di analisis menggunakan uji Independent ttest dan paired t-test bila data terdistribusi normal atau uji Mann Whitney bila data tidak terdistribusi normal.

\section{HASIL DAN PEMBAHASAN \\ Karakteristik Responden}

Berdasarkan tabel 1 hasil penelitian menunjukkan bahwa pada kelompok perlakuan ceramah dan video terdapat $52,5 \%$ responden perempuan dan pada kelompok perlakuan ceramah diskusi dan roleplaying terdapat $57,5 \%$ responden perempuan dan sebagian besar responden berumur 15 tahun sebanyak $45 \%$. Hal ini menunjukkan bahwa mayoritas responden termasuk pada kelompok remaja awal yang berada pada kelas X (sepuluh). Hasil penelitian juga menunjukkan mayoritas responden memiliki orangtua dengan pendidikan terakhir SD serta seluruh responden belum pernah mengikuti 
pendidikan kesehatan reproduksi.

Kelompok perlakuan dan kelompok kontrol pada penelitian ini mempunyai karakteristik yang sama karena seluruhnya mempunyai $p$ value $>0,05$ sehingga tidak ada variable karakteristik yang menjadi confounding variable. Demikian juga pada variabel pengetahuan dari kedua kelompok perlakuan dibandingkan dengan kelompok kontrol, seluruhnya tidak ada perbedaan dari ketiga kelompok tersebut dengan $p$ value 0,178 (lihat tabel 2) Hal ini disebabkan karena mayoritas responden belum pernah mendapatkan pendidikan kesehatan reproduksi. Dengan demikian dapat disimpulkan bahwa pengetahuan antara kelompok perlakuan ceramah dan video serta kelompok perlakuan ceramah, diskusi kasus dan role playing tidak berbeda atau homogen dibandingkan dengan kelompok control. Hal ini menguntungkan untuk penelitian ini karena pengetahuan awal dari kedua kelompok perlakuan dan kontrol sama.

Tabel 1. Karakteristik Responden

\begin{tabular}{|c|c|c|c|c|c|c|c|}
\hline \multirow[t]{2}{*}{ Variabel } & \multicolumn{2}{|c|}{$\begin{array}{c}\text { Kelompok } \\
\text { Perlakuan A } \\
\end{array}$} & \multicolumn{2}{|c|}{$\begin{array}{c}\text { Kelompok } \\
\text { Perlakuan B } \\
\end{array}$} & \multicolumn{2}{|c|}{$\begin{array}{c}\text { Kelompok } \\
\text { kontrol }\end{array}$} & \multirow[t]{2}{*}{ Pvalue } \\
\hline & $\mathrm{N}$ & $\%$ & $\mathrm{~N}$ & $\%$ & $\mathrm{~N}$ & $\%$ & \\
\hline \multicolumn{8}{|l|}{ Jenis Kelamin } \\
\hline Laki-Laki & 19 & 47,5 & 17 & 42,5 & 19 & 47,5 & 0,878 \\
\hline Perempuan & 21 & 52,5 & 23 & 57,5 & 21 & 52,5 & \\
\hline \multicolumn{8}{|l|}{ Umur } \\
\hline 15 tahun & 20 & 50 & 25 & 62,5 & 23 & 57,5 & 0,051 \\
\hline 16 tahun & 14 & 35 & 9 & 22,5 & 13 & 32,5 & \\
\hline 17 tahun & 6 & 25 & 6 & 15 & 4 & 10,0 & \\
\hline \multicolumn{8}{|l|}{ Pendidikan Ayah } \\
\hline Tidak Tamat SD & 2 & 5 & 3 & 7,5 & 3 & 7,5 & 0,363 \\
\hline SD & 19 & 47,5 & 18 & 45 & 19 & 47,5 & \\
\hline SMP & 7 & 17,5 & 4 & 10 & 10 & 25,0 & \\
\hline SMA & 10 & 25 & 14 & 35 & 6 & 15,0 & \\
\hline $\mathrm{D} 3 / \mathrm{S} 1$ & 2 & 5 & 1 & 2,5 & 2 & 5,0 & \\
\hline \multicolumn{8}{|l|}{ Pendidikan Ibu } \\
\hline Tidak Tamat SD & 5 & 12,5 & 4 & 10 & 7 & 17,5 & 0,350 \\
\hline SD & 19 & 47,5 & 18 & 45 & 18 & 45 & \\
\hline SMP & 10 & 25 & 10 & 25 & 9 & 22,5 & \\
\hline SMA & 4 & 10 & 5 & 12 & 5 & 12,5 & \\
\hline $\mathrm{D} 3 / \mathrm{S} 1$ & 2 & 5 & 3 & 7,5 & 1 & 2,5 & \\
\hline \multicolumn{8}{|l|}{ Pendidikan KRR } \\
\hline Pernah & 0 & 0 & 0 & 0 & 0 & 0 & 0,99 \\
\hline Tidak Pernah & 40 & 100 & 40 & 100 & 40 & 100 & \\
\hline
\end{tabular}


Tabel 2. Distribusi perbedaan rata-rata skor pengetahuan masing-masing kelompok sebelum intervensi

\begin{tabular}{clccccc}
\hline No. & Pengetahuan & Mean & Min & Maks & df & p value \\
\cline { 1 - 4 } 1. & $\begin{array}{l}\text { Kelompok Perlakuan } \\
\text { ceramah dan video }\end{array}$ & 13,55 & 9 & 18 & & \\
\cline { 1 - 4 } 2. & $\begin{array}{l}\text { Kelompok Perlakuan } \\
\text { ceramah, diskusi dan } \\
\text { roleplaying }\end{array}$ & 9,38 & 7 & 19 & 3 & 0,178 \\
\cline { 1 - 3 } 3. & $\begin{array}{l}\text { Kelompok Perlakuan } \\
\text { kontrol }\end{array}$ & 10,38 & 7 & 17 & \\
\hline
\end{tabular}

Tabel 3. Distribusi perbedaan rata-rata skor sikap masing-masing kelompok sebelum intervensi

\begin{tabular}{clccccc}
\hline No. & \multicolumn{1}{c}{ Sikap } & Mean & Min & Maks & df & p value \\
\cline { 1 - 4 } 1. & $\begin{array}{l}\text { Kelompok Perlakuan } \\
\text { ceramah dan video }\end{array}$ & 95,32 & 66 & 114 & & \\
\cline { 1 - 3 } 2. & $\begin{array}{l}\text { Kelompok Perlakuan } \\
\text { ceramah, diskusi } \\
\text { kasus dan roleplaying }\end{array}$ & 89,45 & 60 & 115 & 3 & 0,668 \\
\cline { 1 - 3 } 3. & $\begin{array}{l}\text { Kelompok Perlakuan } \\
\text { kontrol }\end{array}$ & 87,45 & 55 & 120 & & \\
\hline
\end{tabular}

Tabel 4. Pengaruh Pendidikan Kesehatan Reproduksi Melalui Fasilitator BKKBN dan PKBI

\begin{tabular}{|c|c|c|c|c|c|}
\hline \multirow{2}{*}{ Variabel } & \multicolumn{2}{|c|}{ Mean } & \multirow{2}{*}{ SD } & \multirow{2}{*}{$95 \% \mathrm{CI}$} & \multirow{2}{*}{$\mathrm{P}$ value } \\
\hline & Pretest & Posttest & & & \\
\hline \multicolumn{6}{|l|}{ Pengetahuan } \\
\hline $\begin{array}{l}\text { Kelompok Perlakuan } \\
\text { ceramah dan video }\end{array}$ & 13,55 & 28,08 & 0,997 & $27,76-28,39$ & 0,0001 \\
\hline $\begin{array}{l}\text { Kelompok Perlakuan } \\
\text { ceramah, role playing, } \\
\text { diskusi kasus dan } \\
\text { testimoni }\end{array}$ & 9,38 & 28,58 & 1,394 & $28,13-29,02$ & \\
\hline Kelompok kontrol & 10,38 & 11,08 & 0,887 & $27,60-29,39$ & \\
\hline \multicolumn{6}{|l|}{ Sikap } \\
\hline $\begin{array}{l}\text { Kelompok Perlakuan } \\
\text { ceramah dan video }\end{array}$ & 95,32 & 141,1 & 6,071 & $139,16-143,04$ & 0,0001 \\
\hline $\begin{array}{l}\text { Kelompok Perlakuan } \\
\text { ceramah, role playing, } \\
\text { diskusi kasus dan } \\
\text { testimony }\end{array}$ & 89,45 & 139,4 & 4,904 & $137,88-141,02$ & \\
\hline Kelompok kontrol & 87,45 & 138,6 & 4,905 & $137,66-140,04$ & \\
\hline
\end{tabular}

Tidak adanya perbedaan nilai ratarata pengetahuan antara dua kelompok perlakuan dan kelompok kontrol, juga didukung dengan sebagian besar responden $(85 \%)$ ketiga kelompok memiliki orangtua dengan pendidikan terakhir SD. Dengan 
pendidikan orangtua yang hampir sama sehingga tidak jauh berbeda informasi yang mereka dapatkan. Ini berarti bahwa pengalaman merupakan yang paling berharga, karena pesan dapat tersimpan lama sehingga pengetahuan dan sikap dapat meningkat hingga dilakukannya postest, walaupun penyerapan informasi yang diterimanya masih sangat terbatas. ${ }^{(8)}$

Demikian juga berdasarkan uji statistik independent t-test terhadap ratarata nilai sikap responden sebelum diberikan perlakuan menunjukkan bahwa tidak adanya perbedaan atau homogen dengan diperoleh nilai $p$ value adalah 0,668.(lihat table 3) Hal ini disebabkan karena selain mayoritas responden belum pernah mendapatkan pendidikan kesehatan reproduksi juga sikap responden terhadap seksualitas mempunyai pendapat yang sama karena mereka kemungkinan besar terpapar dengan hal yang sama sehingga responden dari ketiga kelompok dapat dikatakan homogen.

Tabel 4 menunjukkan bahwa terdapat peningkatan rata-rata pengetahuan antara sebelum perlakuan dan sesudah perlakuan sebesar 14,53 yaitu dari rata-rata awal 13,55 menjadi rata-rata 28,08 dengan standar deviasi 0,997 pada kelompok fasilitator dengan menggunakan ceramah dan video. Sedangkan pada kelompok perlakuan dengan ceramah diikuti diskusi kasus dan role playing menunjukkan bahwa terdapat peningkatan rata-rata pengetahuan yang lebih tinggi dibandingkan dengan perlakuan ceramah dan video. Kenaikan pengetahuannya sebesar 19,2 yaitu dari rata-rata awal 9,38 menjadi rata-rata 28,58 dengan standard deviasi 1,394. Pengetahuan adalah hasil tahu penginderaan manusia, atau hasil tahu seseorang terhadap objek melalui indra yang dimilikinya (mata, hidung, telinga dan sebagainya). Pada waktu penginderaan sampai menghasilkan pengetahuan tersebut sangat dipengaruhi oleh intensitas, perhatian, focus dan persepsi terhadap objek, sehingga pengetahuan seseorang terhadap objek mempunyai intensitas atau tingkat yang berbeda-beda. ${ }^{(7)}$ Hasil penelitian ini menunjukkan bahwa pemberian pengetahuan melalui proses penginderaan yang lengkap disertai dengan diskusi kasus dan role playing memberikan hasil yang lebih baik dibandingkan dengan melalui ceramah dan video. Responden dalam kelompok ceramah role palying dan diskusi kasus, menggunakan pikirannya lebih banyak dan aktif dibandingkan dengan hanya melihat dan mendengar seperti dikelompok ceramah dan video. Sehingga pengaruh pengetahuan yang diperoleh responden melalui informasi non formal dan dari pengalaman teman dan pribadi membuat responden lebih ingat dan yakin tentang manfaat dari pencegahan perilaku yang diharapkan. 
Hal ini sejalan dengan penelitian Christina (2007) bahwa peran sekolah merupakan sumber informasi kesehatan reproduksi remaja yang berpengaruh kuat dalam membentuk pengetahuan kesehatan reproduksi pada remaja. ${ }^{(13)}$ Penelitian lain juga mengungkapkan bahwa pengetahuan yang diperoleh remaja dari teman maupun dari internet memungkinkan terjadinya kesalahpahaman remaja segala hal yang berkaitan dengan perilaku seks pranikah dibandingkan dengan informasi yang diberikan oleh sekolah. ${ }^{(14)}$

Menurut Sari (2014), upaya pencegahan HIV dan AIDS hanya dapat efektif bila dilaksanakan dengan komitmen seluruh lapisan masyarakat dan komitmen politik yang tinggi untuk mencegah dan atau mengurangi perilaku berisiko tinggi terhadap penularan HIV, selain itu juga dapat dilakukan dengan penyuluhan kesehatan. Penelitian Nursan (2007) menunjukkan bahwa adanya pengaruh pengetahuan tentang kesehatan reproduksi terhadap perilaku seksual remaja. Demikian juga penelitian di Jawa Tengah (Suryoputro, NJ.Ford, Shaluhiyah, 2006) yang menyatakan bahwa pengetahuan yang lengkap seorang remaja tentang kesehatan reproduksi justru cenderung untuk tidak melakukan hubungan seksual pra-nikah. ${ }^{(11)}$ Namun hal ini bukan hanya pengetahuan tentang kesehatan reproduksi, IMS dan HIV/AIDS yang menentukan seseorang berperilaku berisiko tetapi kemungkinan ada faktor lain juga sebagai perantara yang menghubungkan dengan perilaku seksual remaja. $^{(12)}$

Hal ini didukung pula oleh pendapat Dalyono (2007) bahwa intelegensia seseorang dipengaruhi beberapa faktor yaitu pembawaan, pembentukan, minat dan pembawaan yang khas serta kebebasan. Misalkan dalam pembentukan pengetahuan dapat dilakukan dengan sengaja (pemberian pendidikan kesehatan reproduksi) ataupun tidak sengaja (pengaruh alam sekitar). Dalam pemberian pendidikan kesehatan reproduksi pada responden yang pernah terpapar tentang materi sistem reproduksi manusia sehingga lebih melekat pada ingatannya yang sering dialami. Sehingga saat diberikan pendidikan kesehatan reproduksi akan mudah menyerap materi yang diberikan. Diperkuat oleh Hartono (1999) bahwa dalam prinsip-prinsip perkembangan salah satunya adanya perbedaan individu, artinya di dalam proses perkembangan setiap individu memiliki sifat dan karakteristik sendiri, berbeda satu dengan yang lain baik menyangkut kecepatan atau kelambatannya. Ada individu yang lebih cepat pada tahapan tertentu, akan tetapi lebih lambat pada tahapan atau aspek yang lain. Sehingga konsekuensinya tidak ada dua individu yang mempunyai kesamaan 
dalam perkembangannya meskipun kembar. $^{(3)}$

Hal ini sesuai dengan tujuan pendidikan kesehatan yang dikemukakan Emelian (2008) bahwa pendidikan kesehatan adalah suatu upaya atau kegiatan untuk menciptakan perilaku masyarakat yang kondusif untuk kesehatan. Artinya pendidikan kesehatan berupaya agar masyarakat menyadari atau mengetahui bagaimana cara memelihara kesehatan, bagaimana menghindari atau mencegah hal-hal yang merugikan kesehatannya dan orang lain, kemana seharusnya mencari pengobatan bilamana sakit dan sebagainya. Menurut Notoatmodjo (2012), semakin tinggi pendidikan seseorang maka daya tangkap informasi semakin tinggi, sehingga akan semakin mudah untuk menerima informasi. Selain itu, informasi juga dapat mempengaruhi pengetahuan remaja, informasi tersebut berasal dapat berupa media cetak, elektronik dan sosialisai dari petugas kesehatan. ${ }^{(10)}$

Dalam hal sikap responden tabel 4 menunjukkan bahwa terdapat peningkatan rata-rata sikap pada kelompok perlakuan ceramah, diskusi kasus dan role playing antara sebelum perlakuan dan sesudah perlakuan sebesar 49,95 yaitu dari rata-rata awal 89,45 menjadi rata-rata 139,4 dengan standar deviasi 4,9 dengan $p$ value 0,001. Demikian juga terjadi peningkatan ratarata sikap pada kelompok perlakuan ceramah dan video antara sebelum dan sesudah perlakuan sebesar 45,78 yaitu dari rata-rata 95,32 menjadi rata-rata 141,1 dengan standar deviasi 6,071 dengan nilai $\mathrm{p}$ value 0,001 . Perbandingan terhadap perbedaan nilai rata-rata sikap responden pada kedua kelompok perlakuan yang meningkat secara statistik signifikan dibandingkan kontrol. Kelompok perlakuan ceramah dengan role playing dan diskusi kasus terlihat mempunyai skor sikap yang lebih tinggi dibandingkan kelompok ceramah dan video, hal ini karena pemberian materi pendidikan kesehatan reproduksi selain dengan ceramah dan tanya jawab tetapi juga diberikan kesempatan untuk diskusi kasus dan problem solving, curah pendapat serta role play. Memori setiap individu berbeda dan pada pembelajaran melalui fasilitator yang lebih melibatkan keaktifan responden artinya aspek psikomotor mampu menguatkan kognitif, sehingga dapat membentu sikap lebih baik. ${ }^{(9)}$

Berdasarkan teori Green yang menyatakan bahwa sikap merupakan faktor predisposing yang berpengaruh terhadap perilaku seseorang. Perubahan sikap tidak sesederhana perubahan pengetahuan. Untuk memberntuk sikap atau kesediaan seseorang untuk berperilaku yang ditawarkan, seseorang membutuhkan keyakinan yang kuat akan manfaat dari perilaku tersebut. Pernyataan tersebut 
diperkuat dengan pernyataan Notoatmodjo yang menyatakan bahwa adanya informasi atau pengetahuan yang sering berulangulang maka dapat meningkatkan pengetahuan seseorang dan meningkatkan keyakinan seseorang yang berasal dari pengalaman sendiri atau pengalaman orang lain akan meningkatkan sikap seseorang. ${ }^{(10)}$

Sikap merupakan kecenderungan yang berasal dari dalam diri individu untuk berkelakuan dengan pola-pola tertentu, terhadap suatu obyek akibat pendirian dan perasaan terhadap obyek tersebut. Sikap yang utuh pada seseorang dapat terbentuk jika terdapat kepercayaan (keyakinan), ide dan konsep terhadap suatu obyek, kehidupan emosional atau evaluasi emosional terhada suatu obyek dan kecenderungan bertindak. Penentuan sikap yang utuh ini, pengetahuan, berpikir, keyakinan dan emosi memegang peranan penting. Sikap responden dalam penelitian ini adalah bentuk kesiapan dan ketersediaan responden dalam melakukan pencegahan perilaku seks berisiko yang dimulai dari kesiapan pengetahuan dan pemahaman kesehatan reproduksi. ${ }^{(15)}$

Pemberian pendidikan kesehatan reproduksi dengan mendengarkan ceramah dari diberikan kesempatan diskusi dan membahas pengalaman orang lain diikuti dengan cara role play dan diskusi mendalam diikuti dengan problem solving membuat seseorang menjadi belajar lebih aktif dan kreatif dalam memecahkan masalah sehingga membuat mereka merasa terlibat dalam kasus tersebut. Dengan memberi kesempatan responden lebih akif dalam proses penerimaan materi yang diberikan membuat pengetahuan yang diperoleh lebih bertahan lama dan sulit terlupakan. Hal ini sesuai dengan teori yang disampaikan Allport bahwa agar mencapai sikap yang utuh maka pengetahuan berpikir, keyakinan dan emosi sangat berperan penting. Sehingga jika terdapat kesiapan berpikir maka akan terbentuk sikap yang utuh dan positif.

Pada metode ceramah dan tanyajawab yang dibantu alat berupa video secara garis besar proses pembelajaran dengan komunikasi satu arah saja dan menurut Mass dan Husowowijoyo (1991) bahwa metode ceramah tanya jawab terkesan bahwa proses pembelajaran bukan lagi hal yang menarik dan akan mudah dilupakan oleh remaja. Ini membuktikan bahwa belajar bermula dari suatu masalah yang ditemukan. Dengan melibatkan peran aktif responden dalam mencari solusi dalam memecahkan masalah, bekerjasama dalam kelompok dengan adanya fasilitor yang intens selama proses belajar maka akan menemukan ide yang spesifik. Sehingga dengan cukup adanya pengetahuan, emosi yang terkendali dan keyakinan dalam berpikir maka responden 
dapat terwujud sikap yang utuh dalam bentuk responden mampu mengidenifikasi masalah serta merancang metode pemecahan masalah dengan potensi yang mereka miliki.

Pendidikan kesehatan reproduksi yang komprehensif dapat meningkatkan penolakan hubungan seks sebelum menikah serta mengurangi kemungkinan remaja terlibat pada perilaku seks berisiko. ${ }^{(16)}$ Sikap merupakan sistem yang berubah-ubah dalam penilaian positif dan negatif, emosi dan kecenderungan untuk setuju dan tidak setuju pada objek sosial yang akan dinilainya. Menurut Newcomb dalam Notoatmodjo (2003), sikap dapat dipelajari berdasarkan pengetahuan, berfikir, keyakinan yang akan menjadi suatu kebiasaan melalui proses belajar. Sikap merupakan manifestasi yang tidak dapat dilihat secara langsung oleh manusia, sikap ini hanya dapat ditafsirkan dari perilaku yang tertutup. Hal ini sejalan dengan penelitian Husodo dan Widagdo (2008) yang menyatakan bahwa sikap remaja setelah mendapat pendidikan tentang kesehatan reproduksi menjadi sikap positif atau mendukung ${ }^{(13)}$

\section{SIMPULAN}

Pendidikan kesehatan reproduksi melalui ceramah, studi kasus dan roleplaying memberikan peningkatan pengetahuan dan sikap yang lebih baik dibandingkan dengan metoda ceramah dan video. Model metode pembelajaran aktif dan kreatif remaja lebih mudah diterima oleh remaja sesuai dengan karakter remaja yang punya tingkat curiositas yang tinggi terutama dalam hal seksualitas dan kesehatan reproduksi. Sehingga memberikan pemahaman dan keyakinan remaja yang lebih baik dan lebih laten. Namun dalam hal ini keterbatasan waktu belajar yang terbatas mempengaruhi dalam pencapaian perubahan perilaku yang optimal. Dalam meningkatkan pemahaman remaja tentang kesehatan reproduksi dan seksualitas yang lengkap diperlukan dengan pemberian pendidikan yang sesuai dengan karakter remaja sehingga mudah diterima remaja dan pada akhirnya dapat meningkatkan pencegahan perilaku seks berisiko pada remaja.

\section{UCAPAN TERIMA KASIH}

Peneliti mengucapkan terima kasih yang sebesar-besarnya kepada Lembaga Pengelola Dana Pendidikan (LPDP) Kementerian Keuangan Republik Indonesia yang telah membiayai penelitian ini serta semua pihak yang telah membantu terlaksananya penelitian ini seperti responden yang telah berpartisipasi dalam penelitian termasuk perijinan dari sekolah yang terlibat. 


\section{KEPUSTAKAAN}

1. Herwanto, Yeni T. Penggunan Facebook Group Sebagai Media Promosi Kesehatan Dalam Upaya Meningkatkan Pengetahuan dan Sikap Remaja Tentang Kesehatan Reproduksi dan HIV/AIDS (Studi di Kota Semarang). Semarang Univ Diponegoro.

2. Badan Pusat Statistik, Badan Koordinasi Keluarga Berencanan Nasional, Departemen Kesehatan, Macro International. Survei Demografi dan Kesehatan Indonesia 2012. Sdki. 2013;16.

3. Mamdy Z N, Tafal Z, Sudarti K. Perencanaan Pendidikan Kesehatan Sebuah Pendekatan Diagnosis. Jakarta: Rineka Cipta. 2006;

4. Suarta. Pendidikan Seksual dan Reproduksi Berbasis Sekolah. 2010;

5. Turaeni Thutju. Pelaksanaan Pengajaran Pendidikan Kesehatan Reproduksi Remaja (PKPR) Sekolah Menengah Atas Negeri (SMAN) Binaan Puskesmas Pelayanan Kesehatan Reproduksi Esensial (PKRE) di Kabupaten Majalangka. Jakarta Kementeri Kesehat Republik Indones. 2006;

6. Hadisaputro,S. Faktor-Faktor Predisposisi Praktik Pendidikan Kesehatan Reproduksi Remaja [Internet]. Vol. 5, Jurnal Kesehatan
Masyarakat. 2009. Available from: http://journal.unnes.ac.id/nju/index. php/kemas/article/view/1854

7. Maulana HDJ. Promosi Kesehatan. Jakarta EGC. 2009;i-271.

8. Usman Moh. Uzer. Menjadi Guru Profesional. Bandung: Remaja Rosdakarya. 2005;

9. Moeliono L. Proses Belajar Aktif Kesehatan Reproduksi Remaja, Bahan Pegangan untuk Memfasilitasi Kegiatan Belajar Aktif untuk Anak \& Remaja. Jakarta EGC. 2006;

10. Notoatmodjo S. Ilmu perilaku kesehatan. Jakarta: Rineka Cipta. 2010;20-40.

11. Suryoputro A, Ford NJ, Shaluhiyah Z. Faktor-Faktor Yang Mempengaruhi Perilaku Seksual Dan Layanan Kesehatan Seksual Dan Reproduksi. Mkara, Kesehat. 2006;10(1):29-40.

12. Megatsari, H. Pengembangan Media KIE Kesehatan Reproduksi di Pondok Pesantren. Surabaya Univ Airlangga. 2007;

13. Cahyo K, Kurniawan TP, Margawati A. Faktor-Faktor Yang Mempengaruhi Praktik Kesehatan Reproduksi Remaja Di SMA Negeri 1 Purbalingga Kabupaten Purbalingga. J Promosi Kesehat Indones [Internet]. 2008;3(2):86- 
Jurnal Promosi Kesehatan Indonesia Volume 14 / No. 1 / Januari 2019

101. Available from:

Perilaku Pencegahan Infeksi

http://www.ejournal.undip.ac.id/ind Menular Seksual. Jakarta Fak ex.php/jpki/article/view/2540

Kesehat Masy Univ Indones. 2015;

14. Limoy M, Panjaitan AA. Remaja Dengan Sikap Seks Pranikah Pada Siswa Kelas XI. J Kebidanan [Internet]. 2017;7:33-9. Available from:http://journal.akpb.ac.id/index. $\mathrm{php} / \mathrm{JK} /$ article/view/17

15. Panjaitan AA, Agustini I. FaktorFaktor yang Berhubungan dengan

16. Putri E, Panjaitan AA. Hubungan Pengetahuan Dengan Sikap Remaja Kelas VIII Terhadap Seks Pranikah Di SMP N 1 Sungai Kakap Tahun 2015. J Kebidanan [Internet]. 2016;6:37-43. Available from: http://journal.akpb.ac.id/index.php/J K/article/view/36 